\title{
Fertility Evaluation of Limed Brazilian Soil Polluted with Scrap Metal Residue
}

\author{
Flávia Almeida Gabos, Aline Reneé Coscione, \\ Ronaldo Severiano Berton, and Gláucia Cecília Gabrielli dos Santos
}

Centro de Solos e Recursos Ambientais-IAC/APTA, Cx. Postal 28, 13012-970 Campinas, SP, Brazil

Correspondence should be addressed to Ronaldo Severiano Berton; berton@iac.sp.gov.br

Received 14 March 2013; Accepted 8 July 2013

Academic Editor: María Cruz Díaz Álvarez

Copyright ( 2013 Flávia Almeida Gabos et al. This is an open access article distributed under the Creative Commons Attribution License, which permits unrestricted use, distribution, and reproduction in any medium, provided the original work is properly cited.

\begin{abstract}
The aim of this work was to characterize the main inorganic contaminants and evaluate the effect of lime addition, combined with soil dilution with uncontaminated soil, as a strategy for mitigation of these contaminants present in a soil polluted with auto scrap. The experiment was performed in a greenhouse at Campinas (São Paulo State, Brazil) in plastic pots $\left(3 \mathrm{dm}^{-3}\right)$. Five soil mixtures, obtained by mixing an uncontaminated soil sample with contaminated soil $(0,25,50,75$, and $100 \%$ contaminated soil), were evaluated for soil fertility, availability of inorganic contaminants, and corn development. In addition to the expected changes in soil chemistry due to the addition of lime, only the availability of $\mathrm{Fe}$ and $\mathrm{Mn}$ in the soil mixtures was affected, while the available contents of $\mathrm{Cu}, \mathrm{Zn}, \mathrm{Cd}, \mathrm{Cr}, \mathrm{Ni}$, and $\mathrm{Pb}$ increased to some extent in the soil mixtures with higher proportion of contaminated soil. Liming of $10 \mathrm{tha}^{-1}$ followed by soil dilution at any proportion studied was not successful for mitigation of the inorganic contaminants to a desired level of soil fertility, as demonstrated by the available amounts extracted by the DTPA method (Zn, $\mathrm{Pb}, \mathrm{Cu}, \mathrm{Ni}, \mathrm{Cr}, \mathrm{Cd}$ ) and hot water (B) still present in the soil. This fact was also proved by the phytotoxicity observed and caused by high amounts of $\mathrm{B}$ and $\mathrm{Zn}$ accumulating in the plant tissue.
\end{abstract}

\section{Introduction}

In many parts of the world, soil is still considered as an option for waste disposal, acting simultaneously as a filter that protects the groundwater and as a bioreactor in which many pollutants may be degraded or stored [1]. Thus, inorganic chemical elements accumulate in soil as a result of human activities.

The monitoring and remediation of contaminated soil are relatively new processes in Brazil, introduced less than 20 years ago. The environmental agency of São Paulo State (CETESB) is a pioneer in the country and has identified more than 4,131 contaminated areas in that state, of which at least $13 \%$ are contaminated exclusively by the addition of heavy metals to the soil [2].

Soil contamination by heavy metals requires an effective and affordable solution due to their potential toxicity and high persistence [3]. Among the so-called heavy metals, elements such as $\mathrm{Cu}$ (copper), $\mathrm{Pb}$ (lead), and $\mathrm{Zn}$ (zinc) are important contaminants because high quantities of these elements can decrease crop production and due to the risk of biomagnification and bioaccumulation in the food chain [4, 5]. Other inorganic contaminants that are not as frequently considered, such as B (boron) and Ba (barium), can be extremely toxic to some plants at concentrations only slightly higher than levels that are optimum for others [6].

The boron requirement of plants is small, with a narrow concentration range from deficiency to toxicity. In arid and semiarid areas, B toxicity results from high levels of B in soils and from the addition of B via irrigation [7-9]. Considerable research has shown the potential toxicity of $\mathrm{Ba}$ in plants, but such studies were short-term and performed in nutrient solutions $[10,11]$.

Although a number of techniques have been developed to remove inorganic contaminants from soils, many sites remain untreated due to high economic costs, and mitigation must be considered. Mitigation can be used to reduce further undesirable impacts on chemical and physical soil degradation, 
to immobilize contaminants and to enable plant growth in contaminated areas to protect the soil from erosion [12-14]. Liming and the addition of organic materials are considered the most promising mitigation techniques for reducing the availability of heavy metals in soil [15-17].

The aim of this work was to characterize the main contaminants and evaluate the effect of lime addition, combined with soil dilution with uncontaminated soil, as a strategy for mitigation of inorganic contaminants present in a soil polluted with auto scrap residue.

\section{Materials and Methods}

2.1. Site Description. The studied soil samples were collected from a polluted area located in Piracicaba, São Paulo State, Brazil $\left(22^{\circ} 42^{\prime} 30^{\prime \prime} \mathrm{S} ; 47^{\circ} 38^{\prime} 01^{\prime \prime} \mathrm{W}\right)$, which was cultivated with sugarcane before the contamination event, which occurred in 2005. The soil studied is a eutrofic technic leptosol in association with an endodystric leptic cambisol. This soil is intensively cultivated with either sugarcane or pastures in the Piracicaba city region (more than 300,000 ha). The climate is classified as Cwa (tropical moist), according to Köppen, with rainy summers and dry winters. June, July, and August are the driest months, the average temperature of the warmest month is higher than $22^{\circ} \mathrm{C}$, and the temperature drops below $16^{\circ} \mathrm{C}$ in the coldest month. The annual average temperature is $21.5^{\circ} \mathrm{C}$, and the precipitation is $1,270 \mathrm{~mm}$ [18].

Scrap metal residue was discarded on arable land and incorporated unevenly into the soil. After local environmental agency (CETESB) intervention, $10 \mathrm{tha}^{-1}$ of dolomitic limestone was applied (April 2005) in an attempt to increase the $\mathrm{pH}$ and to precipitate the metals.

The total inorganic contaminant content of the waste and the soil samples was extracted using the nitric acidmicrowave oven digestion method EPA-3051, with determination by inductively coupled plasma-optical emission spectrometry (ICP-OES) [19].

The chemical composition of the waste (dry weight basis) was $\mathrm{P}=0.6, \mathrm{~K}=0.8, \mathrm{Ca}=10.9, \mathrm{Mg}=12.3$, and $\mathrm{S}=1.5 \mathrm{~g} \mathrm{~kg}^{-1}$, and $\mathrm{Al}=7,449, \mathrm{~B}=170, \mathrm{Ba}=919, \mathrm{Cd}=7.4, \mathrm{~Pb}=775, \mathrm{Cu}=$ 2,497, $\mathrm{Fe}=101,603, \mathrm{Mn}=1,115, \mathrm{Ni}=153, \mathrm{Cr}=178$, and $\mathrm{Zn}=$ $8,157 \mathrm{mg} \mathrm{kg}^{-1}$.

Due to heterogeneity in the disposal, for all of the research developed within this area, the region was divided into twelve subareas of approximately $2,450 \mathrm{~m}^{2}$ each for chemical analysis. Soil samples were taken from the 0 to $20 \mathrm{~cm}$ depth layer, dried at room temperature and sieved to $2.0 \mathrm{~mm}$, and the total heavy metal content was analyzed (Table 1). The soil from subarea number four was selected for the experiment because its composition was close to the average for most of the elements found in the sub-areas considered. One uncontaminated soil sample (SC) was obtained in the vicinity of the contaminated area, at the same depth.

2.2. Greenhouse Experiment. The experiment was performed in a greenhouse at Campinas (São Paulo State, Brazil) in plastic pots $\left(3 \mathrm{dm}^{3}\right)$. Four soil mixtures, obtained by mixing the uncontaminated soil sample (SC) and contaminated soil from subarea 4 (CA4) to create a gradient of contamination, were evaluated for soil fertility, chemical contaminant availability, and corn development.

The experimental design used randomized complete blocks with five proportions $(0,25,50,75$, and $100 \%)$ of contaminated soil, with five replicates. The soil mixtures were carefully homogenized and incubated at room temperature for 10 days, with the soil moisture maintained at $70 \%$ of the soil's water holding capacity (WHC).

After incubation, the soil samples were collected, air dried, and sieved through a $2 \mathrm{~mm}$ mesh screen and then submitted to chemical characterizations for soil fertility and available metal content as explained in the site description (Table 3).

The corn cultivar cv. Al Bandeirantes-CATI was seeded at a rate of ten seeds per pot. Seedlings were thinned to five per pot after emergence. During the cultivation, the soil moisture was maintained at $70 \%$ field capacity by watering regularly for water loss. The only nutrient added to the pots was nitrogen, as ammonium nitrate, in four applications of 50, 100, 250, and $250 \mathrm{mg} \mathrm{pot}^{-1}$, respectively at 7, 14, 21, and 28 days after emergence.

The plants were harvested 45 days after emergence. The shoots were selected to evaluate the metal phytoavailability.

2.3. Soil Fertility Analyses. Soil fertility attributes were determined by São Paulo State official methods developed at Instituto Agronomico [20] and consisted, briefly, of soil $\mathrm{pH}$ measured in a $0.01 \mathrm{~mol} \mathrm{~L}^{-1}$ calcium chloride solution $\left(\mathrm{pHCaCl}{ }_{2}\right)$ with a soil solution ratio of $1: 2.5 ; \mathrm{H}+\mathrm{Al}$ extracted by the SMP buffer; phosphorus $(\mathrm{P})$, potassium $(\mathrm{K})$, calcium $(\mathrm{Ca})$, and magnesium $(\mathrm{Mg})$ extracted by the mixed ion-exchange resin method with cation determination by AAS and P-determination spectrophotometry using the blue molibdate method; organic matter (OM) oxidized with potassium dichromate and determined by photometry; cation exchange capacity (CEC) and base saturation (SB) obtained by calculation; sulfate (S) extracted by calcium phosphate and determined by turbidimetry; available $\mathrm{Zn}, \mathrm{Cu}, \mathrm{Fe}, \mathrm{Mn}, \mathrm{Cd}$, $\mathrm{Cr}, \mathrm{Ni}$, and $\mathrm{Pb}$ contents extracted with DTPA-TEA solution at $\mathrm{pH} 7.3$ and determined by ICP-AES; and B contents extracted with hot water and determined photometrically with azomethine- $\mathrm{H}$.

2.4. Plant Analyses. After harvesting, the plant material was rinsed thoroughly with tap water, followed by $1 \% \mathrm{HCl}$ solution and then deionized water. After the excess water flowed off, each sample was placed in a paper bag and dried in a forced air oven at $70^{\circ} \mathrm{C}$ until a constant weight was achieved; the samples were then weighed and ground in a Wiley-type grinder. Each sample was submitted to oven digestion (incineration) according to Bataglia et al. [21], and the extracts were analyzed for $\mathrm{P}, \mathrm{K}, \mathrm{Ca}, \mathrm{Mg}, \mathrm{S}, \mathrm{B}$, $\mathrm{Cu}, \mathrm{Mn}, \mathrm{Zn}, \mathrm{Fe}, \mathrm{Cd}, \mathrm{Cr}, \mathrm{Ni}$, and $\mathrm{Pb}$ by induced coupled plasma emission spectrometry (ICP-OES) (Varian, Vista MPX, Australia). Nitrogen contents were determined using a sulfuric digestion extract using the steam distillation method [22]. 
TABLE 1: Heavy metal concentrations of the twelve subareas analyzed.

\begin{tabular}{|c|c|c|c|c|c|c|c|}
\hline \multirow[b]{2}{*}{ Subarea } & \multicolumn{7}{|c|}{ Total content ${ }^{\mathrm{a}}$} \\
\hline & $\mathrm{Ba}$ & $\mathrm{Cd}$ & $\mathrm{Pb}$ & $\begin{array}{c}\mathrm{Cu} \\
\mathrm{mg} \mathrm{kg}\end{array}$ & $\mathrm{Cr}$ & $\mathrm{Ni}$ & $\mathrm{Zn}$ \\
\hline $\mathrm{SAl}^{\mathrm{b}}$ & 311 & 3.6 & 332 & 198 & 110 & 52 & 1,811 \\
\hline $\mathrm{SA} 2^{\mathrm{b}}$ & 696 & 8.8 & 632 & 150 & 15 & 39 & 3,225 \\
\hline $\mathrm{SA} 3^{\mathrm{b}}$ & 322 & 3.2 & 357 & 250 & 118 & 48 & 3,371 \\
\hline $\mathrm{SA} 4^{\mathrm{b}}$ & 619 & 6.4 & 254 & 172 & 105 & 55 & 2,223 \\
\hline $\mathrm{SA} 5^{\mathrm{b}}$ & 327 & 4.0 & 238 & 147 & 99 & 32 & 1,890 \\
\hline $\mathrm{SA} 6^{\mathrm{b}}$ & 306 & 13.5 & 198 & 265 & 130 & 30 & 1,985 \\
\hline $\mathrm{SA} 7^{\mathrm{b}}$ & 263 & 2.1 & 178 & 199 & 102 & 41 & 1,411 \\
\hline $\mathrm{SA} 8^{\mathrm{b}}$ & 314 & 2.2 & 211 & 131 & 114 & 49 & 1,678 \\
\hline SA $9^{\mathrm{b}}$ & 881 & 12.6 & 438 & 115 & 198 & 52 & 2,102 \\
\hline $\mathrm{SA} 10^{\mathrm{b}}$ & 365 & 4.0 & 167 & 201 & 85 & 102 & 1,721 \\
\hline $\mathrm{SA}_{11}^{\mathrm{b}}$ & 487 & 14.2 & 451 & 389 & 190 & 61 & 2,930 \\
\hline $\mathrm{SA} 12^{\mathrm{b}}$ & 291 & 7.0 & 244 & 108 & 112 & 51 & 2,014 \\
\hline Mean & 432 & 6.8 & 308 & 194 & 115 & 51 & 2,197 \\
\hline $\mathrm{SC}^{\mathrm{c}}$ & 109 & $<0.1$ & 13 & 7 & 34 & 2.0 & 20 \\
\hline
\end{tabular}

${ }^{a}$ SW-846 3051 method [19].

${ }^{\mathrm{b}}$ Contaminated soil sample.

${ }^{c}$ Uncontaminated soil sample.

2.5. Data Analysis. The results of the soil and plant analyses were submitted to an analysis of variance $(P<0.05)$. When significant, the results obtained were also examined using regression analysis (linear and quadratic models). The software used was SISVAR 4.0 [23] and XLSTAT Pro 7.0.

\section{Results and Discussion}

3.1. Soil Analysis. The total contents of $\mathrm{Cu}-160 \mathrm{mg} \mathrm{kg}^{-1}$, $\mathrm{Cr}-103 \mathrm{mg} \mathrm{kg}^{-1}, \mathrm{Ni}-47 \mathrm{mg} \mathrm{kg}^{-1}, \mathrm{Cd}-8.2 \mathrm{mg} \mathrm{kg}^{-1}, \mathrm{~Pb}-$ $268 \mathrm{mg} \mathrm{kg}^{-1}$, and $\mathrm{Zn}-2,454 \mathrm{mg} \mathrm{kg}^{-1}$ were above the maximum content commonly found in the soils of São Paulo (Table 2). The total metal content reference levels in soils established by CETESB are (in $\mathrm{mg} \mathrm{kg}^{-1}$ ) $\mathrm{Cu}-35,60,200$; $\mathrm{Pb}-17,72,180 ; \mathrm{Zn}-60,300,450 ; \mathrm{Cd}-<0.5,1.3,3.0$; $\mathrm{Cr}-$ $40,75,150 ; \mathrm{Ni}-13,30,70$, and $\mathrm{Ba}-75,150,300$, respectively, for quality (Quality Reference Level-the concentration of a substance in soil that defines a ground as clean or of natural quality. This level should be used as a reference in the prevention of soil pollution and the control of contaminated areas.), prevention (Prevention Level-the concentration of a substance above which changes to soil quality may occur. This level should be used to regulate the introduction of substances into a soil. When this level is exceeded, continued activity shall be subject to further evaluation.), and agricultural intervention (Intervention Level-the concentration of a substance in soil above which potential risks, direct or indirect, to human health may occur. For soil, this level is calculated using the risk assessment procedure to human health exposure scenarios for agricultural, residential, and industrial protection. The area is classified as an investigational contaminated area when the presence of contaminants is found in the soil at concentrations above the intervention value, indicating the requirement for action to protect the receptors of risk.) [24].

Considering such values, the amounts of $\mathrm{Cu}, \mathrm{Cr}$, and $\mathrm{Ni}$ fell between the levels of prevention and agricultural intervention. The amounts of $\mathrm{Cd}$ and $\mathrm{Pb}$ fell between the levels of agriculture and residential intervention. The most critical value was obtained for $\mathrm{Zn}$, which was $50 \%$ higher than the industrial prevention level. No reference values are provided for Mn or B by the local environmental agency. However, considering the limits for Austrian soil $\left(100 \mathrm{mg} \mathrm{kg}^{-1}\right)$, the content of boron in the contaminated soil $\left(62 \mathrm{mg} \mathrm{kg}^{-1}\right)$ can be considered high [25]. The concentration of $\mathrm{Ba}$ that was found during soil characterization $\left(241 \mathrm{mg} \mathrm{kg}^{-1}\right)$ is close to the intervention level $\left(300 \mathrm{mg} \mathrm{kg}^{-1}\right)$ [24].

The addition of scrap metal residue and lime to the soil (SA-4) also changed some soil attributes when compared to uncontaminated soil obtained from a neighboring area (Table 2). There was an increase in attributes related both to the lime and to the residue, which were rich in elements such as $\mathrm{B}, \mathrm{Cu}, \mathrm{Zn}, \mathrm{Ni}, \mathrm{Pb}, \mathrm{Cd}, \mathrm{Cr}$, and $\mathrm{Ba}$.

The DTPA method, originally proposed by Lindsay and Norvell [26] to evaluate micronutrient availability for agricultural purposes, can also be helpful in monitoring soil contamination with heavy metals [27]. According to Abreu et al. [28], the available micronutrients in Brazil's soils fall into the following ranges (in $\mathrm{mg} \mathrm{dm}^{-3}$ ): $\mathrm{B}-0.01-10.6$; $\mathrm{Cu}-$ $0.1-56 ; \mathrm{Mn}-1-325 ; \mathrm{Pb}-0.00-63.9$; and $\mathrm{Zn}-1-453$, while the respective average values for São Paulo State were B-0.32; $\mathrm{Cu}-2.5 ; \mathrm{Mn}-16 ; \mathrm{Pb}-0.85$; and $\mathrm{Zn}-4.8$. Higher values are indicative of anthropogenic inputs, either due to excessive application of fertilizers or urban and industrial wastes resulting from industrial or mining activities. Thus, the available levels of B and heavy metals (Table 3 ) found in 
TABLE 2: Total element content, available content of heavy metals, and fertility evaluation of the original soil samples studied.

\begin{tabular}{|c|c|c|c|c|c|c|c|c|c|c|}
\hline \multicolumn{11}{|c|}{ Soil fertility attributes $^{\mathrm{a}}$} \\
\hline Soil & $\begin{array}{c}\mathrm{OM} \\
\mathrm{g} \mathrm{kg}^{-1}\end{array}$ & $\mathrm{pH}$ & $\begin{array}{c}\mathrm{P} \\
\mathrm{mg} \mathrm{kg}^{-1}\end{array}$ & $\mathrm{~K}$ & $\mathrm{Ca}$ & $\begin{array}{c}\mathrm{Mg} \\
\mathrm{mmol}_{\mathrm{c}} \mathrm{kg}^{-1}\end{array}$ & $\mathrm{H}+\mathrm{Al}$ & $\mathrm{CEC}^{\mathrm{f}}$ & $\begin{array}{c}\mathrm{SB}^{\mathrm{g}} \\
\%\end{array}$ & \\
\hline $\mathrm{SC}^{\mathrm{d}}$ & 23.2 & 5.2 & 39.0 & 2.3 & 90.8 & 27.6 & 28.0 & 149.0 & 80.6 & \\
\hline $\mathrm{SA} 4^{\mathrm{e}}$ & 26.6 & 7.5 & 25.0 & 2.8 & 285.0 & 66.8 & 9.0 & 363.0 & 97.6 & \\
\hline & \multicolumn{9}{|c|}{$\mathrm{mg} \mathrm{kg}^{-1}$} & $\mathrm{~Pb}$ \\
\hline$S C^{d}$ & 6.4 & 0.23 & 5.3 & 55.0 & 52.3 & 1.9 & 0.1 & $<0.1^{\mathrm{c}}$ & 0.6 & 1.5 \\
\hline $\mathrm{SA} 4^{\mathrm{e}}$ & 56.0 & 14.9 & 29.8 & 47.4 & 15.6 & 325.0 & 0.8 & 0.1 & 2.5 & 18.3 \\
\hline & $\mathrm{Cd}$ & $\mathrm{Pb}$ & $\mathrm{Cu}$ & $\mathrm{Cr}$ & $\begin{array}{c}\mathrm{Ni} \\
\mathrm{Ni} \\
\mathrm{mg} \mathrm{kg}^{-1}\end{array}$ & $\mathrm{Zn}$ & $\mathrm{Ba}$ & B & $\mathrm{Mn}$ & $\begin{array}{c}\mathrm{Fe} \\
\mathrm{g} \mathrm{kg}^{-1}\end{array}$ \\
\hline $\mathrm{SC}^{\mathrm{d}}$ & 2.5 & 13.2 & 30.2 & 18.5 & 7.0 & 38.1 & 107 & 1.8 & 544 & 30 \\
\hline $\mathrm{SA} 4^{\mathrm{e}}$ & 8.2 & 268 & 160 & 103 & 47 & 2450 & 241 & 62 & 498 & 66 \\
\hline
\end{tabular}

${ }^{\text {a }}$ Kabata-Pendias and Pendias 2001 [25].

${ }^{\mathrm{b}}$ USEPA 2007 [19].

${ }^{\mathrm{c}}$ Lower than detection limit.

${ }^{\mathrm{d}} \mathrm{SC}$ : uncontaminated soil.

eSA4: contaminated soil (subarea 4).

${ }^{\mathrm{f}} \mathrm{CEC}$ : cation exchange capacity.

${ }^{\mathrm{g}} \mathrm{SB}$ : base saturation.

the studied area should be of substantial concern due to their high availability to plants and their potential for entering the food chain.

The available contents of $\mathrm{Zn}, \mathrm{B}, \mathrm{Pb}$, and $\mathrm{Cu}$ in the contaminated soil (SA-4) were 171, 75, 12, and 6 times higher, respectively, than the values found in the uncontaminated soil sample (rate 0\%) (Table 3). Even at the lowest rate of contaminated soil used in the soil mixtures (rate 25\%), the dilution effect with uncontaminated soil did not sufficiently reduce the contamination levels to reach the São Paulo availability reference values. Because micronutrients are needed by plants in only minute quantities, plant toxicity and other detrimental effects occur with excess amounts $[29,30]$.

Considering the soil mixtures tested, the soil $\mathrm{pH}$ increased from 5.2 (no contaminated soil added, rate $0 \%$ ) to 7.5 (rate 100\%) This increase is due to the corrective action of lime, releasing $\mathrm{OH}^{-}$ions and consuming $\mathrm{H}^{+}$. The dissolution of limestone also promoted an increase in $\mathrm{Ca}$ and $\mathrm{Mg}$ in the soil, indirectly increasing the CEC and SB as well, while reducing $\mathrm{H}+\mathrm{Al}$ acidity (Table 3 ). Similar effects have been reported for such soil attributes when high $\mathrm{pH}$ residues, such as slag, are used as soil correctives [31, 32].

The phosphorus availability, as measured by the ion exchange method, clearly increased up to the $50 \%$ proportion of contaminated soil and decreased for mixtures enriched with it, as reflected by the 2nd order polynomial used to describe the phosphorus availability behavior (Table 3 ). The lower P availability in soil mixtures with more than $50 \%$ contaminated soil may be explained by the presence of high contents of $\mathrm{Ca}$ and $\mathrm{Mg}$ and the $\mathrm{pH}$ liming effects, with the formation of insoluble calcium phosphate [33].

Regression models were developed to better understand the effect of lime addition (increase in soil $\mathrm{pH}$ ); the increase in contamination by heavy metals in the soil mixtures; soil dilution effect on micronutrient availability and mobility to plants; and plant uptake (Table 3 and Figure 1, Table 4 and Figure 2). Since the linear behavior can be related directly to the soil dilution effect, deviations from linearity can be identified and attributed to changes in elements mobility in soil and availability to plants promoted by liming.

Soil pH is the single factor most consistently cited as the parameter controlling metal solubility and plant availability [36-38]. In general, heavy metal cations and micronutrients, such as $\mathrm{Cu}$ and $\mathrm{Zn}$, are mobile under acid conditions, and increasing the $\mathrm{pH}$ by liming reduces their bioavailability and mobility in soils. The waste contained high levels of $\mathrm{Mn}$ $\left(1,115 \mathrm{mg} \mathrm{kg}^{-1}\right)$ and $\mathrm{Fe}\left(101,603 \mathrm{mg} \mathrm{kg}^{-1}\right)$ and the availability of $\mathrm{Mn}$ to the plants decreased as the soil $\mathrm{pH}$ increased, reducing the element mobility in the soil even in the soil mixtures with higher proportion of contaminated soil (Table 3). Such a decrease also correlates well with the soil pH (Figure 1), but no significant correlation was observed for iron. The availability of most metals is highly reduced at $\mathrm{pH}$ levels higher than 6.0, due to the formation of hydroxides or precipitation as carbonates or phosphates.

Despite liming, the available contents of $\mathrm{Cu}, \mathrm{Zn}, \mathrm{Cd}, \mathrm{Cr}$, $\mathrm{Ni}$, and $\mathrm{Pb}$ increased to some extent in the soil mixtures with higher proportion of contaminated soil (Table 3 ). However, most elements available content also correlated well with the increase in soil pH (Figure 1). Thus, one can conclude that liming was not sufficient to immobilize all such metals.

Cadmium is usually very mobile in soils, although it can precipitate at $\mathrm{pH}$ values higher than 7.0 as carbonate or phosphate compounds [39]. In contrast, $\mathrm{Cu}$ is commonly associated with organic and inorganic compounds, displaying limited mobility in soil, which is further reduced at $\mathrm{pH}$ levels higher than 7.0 [25]. Liming has already been tested without success as an alternative to reduce Cd mobility in 


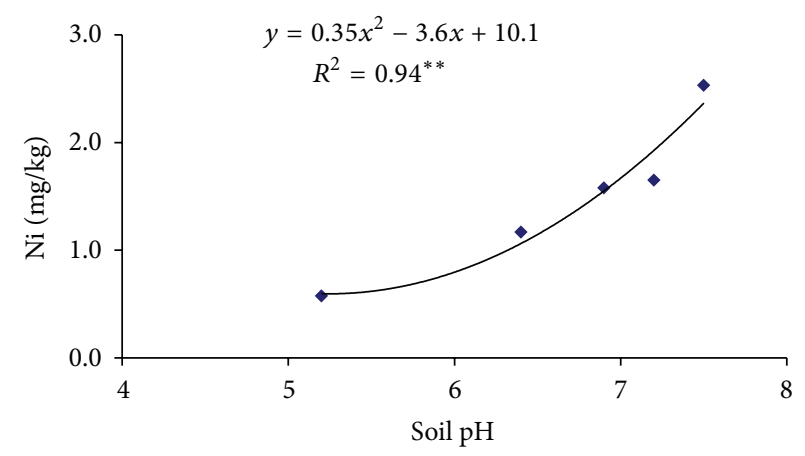

(a)

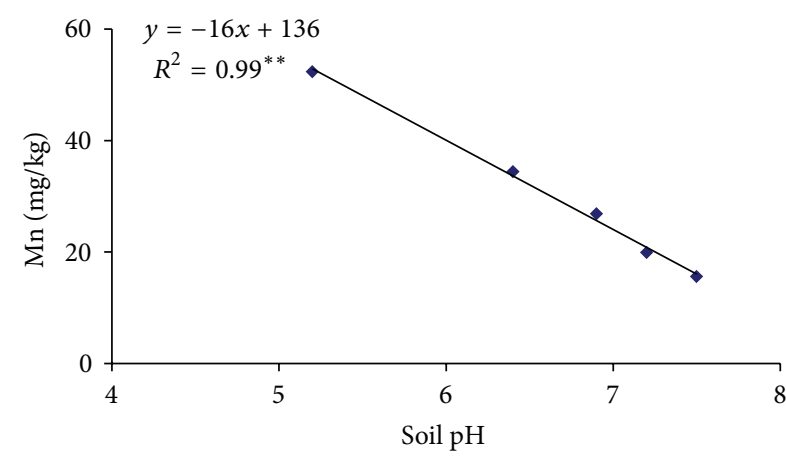

(c)

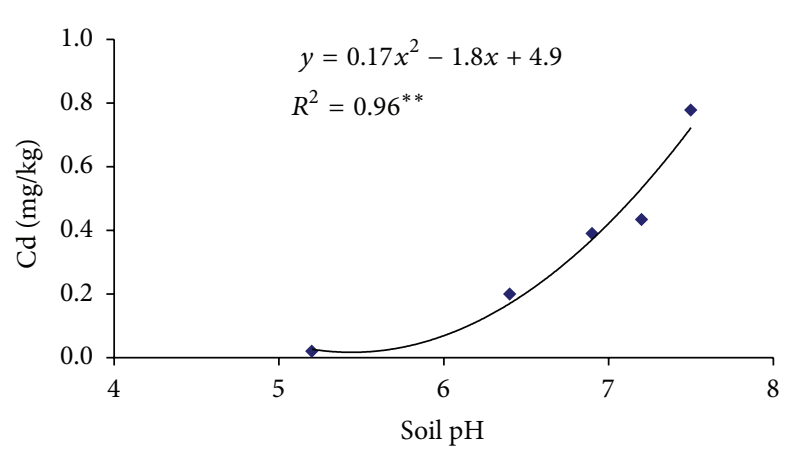

(e)

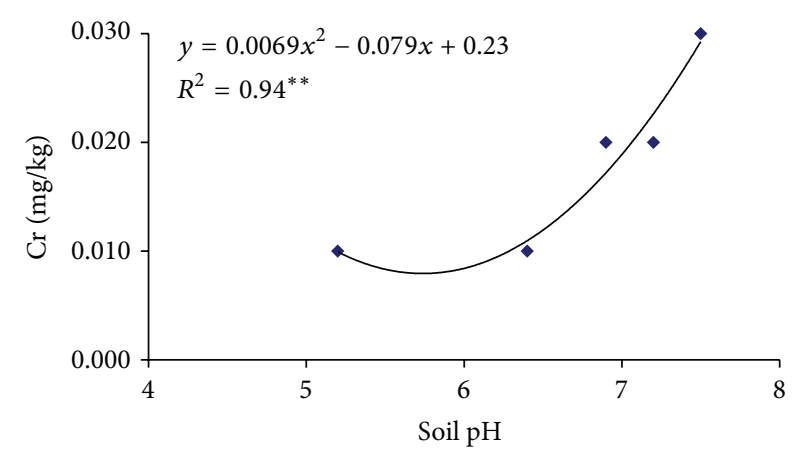

(b)

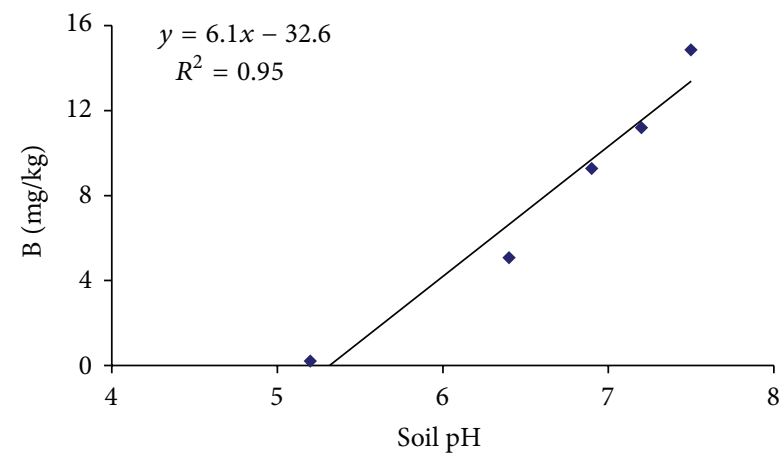

(d)

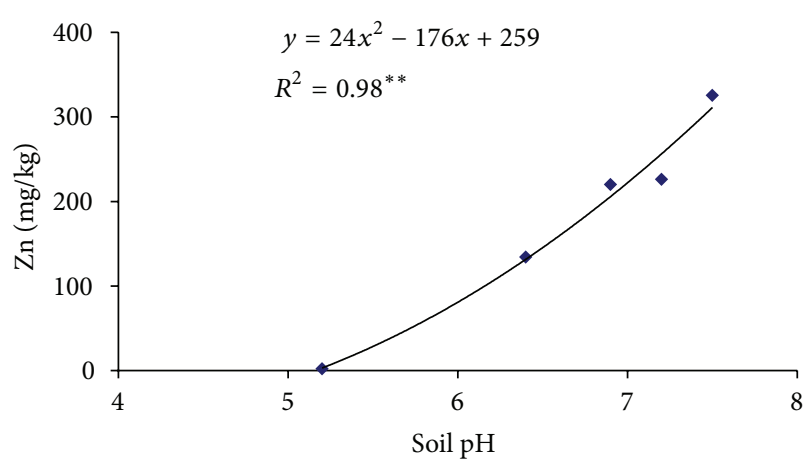

(f)

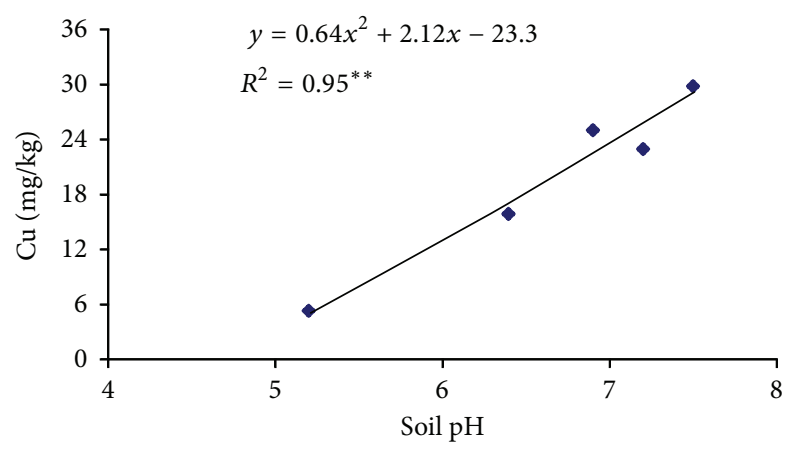

(g)

Figure 1: Effect of soil pH on the some elements availability in the soil mixtures tested. ${ }^{* *}$ Significant at $P<0.01$. 
TABLE 3: Soil fertility and available content of heavy metals in the soil mixtures used in the experiment (after incubation).

\begin{tabular}{|c|c|c|c|c|c|c|c|}
\hline \multirow{2}{*}{ Attribute } & \multicolumn{5}{|c|}{ Proportion of contaminated soil (\%) } & \multirow{2}{*}{ Equation } & \multirow{2}{*}{$\begin{array}{c}\text { Regression coefficient } \mathrm{t}^{\mathrm{a}} \\
R^{2}\end{array}$} \\
\hline & 0 & 25 & 50 & 75 & 100 & & \\
\hline $\mathrm{pH} \mathrm{CaCl}{ }_{2}$ & 5.2 & 6.4 & 6.9 & 7.2 & 7.5 & $y=-2.3 E-04 x^{2}+4.5 E-02 x+5.3$ & $0.98^{*}$ \\
\hline $\mathrm{OM}\left(\mathrm{g} \mathrm{kg}^{-1}\right)$ & 23.2 & 23.8 & 25.3 & 25.6 & 26.6 & $y=-3.2 E-05 x^{2}+3.8 E-02 x+23.13$ & $0.52^{*}$ \\
\hline $\mathrm{P}(\mathrm{mg} \mathrm{kg})$ & 39.0 & 40.6 & 48.2 & 30.0 & 25.0 & $y=0.3 x+38.7$ & $0.52^{*}$ \\
\hline $\mathrm{K}\left(\mathrm{mmol}_{\mathrm{c}} \mathrm{kg}^{-1}\right)$ & 2.3 & 2.0 & 2.7 & 2.4 & 2.8 & $y=5.5 E-05 x^{2}+7.5 E-04 x+2.2$ & $0.27^{*}$ \\
\hline $\mathrm{Ca}\left(\mathrm{mmol}_{\mathrm{c}} \mathrm{kg}^{-1}\right)$ & 90.8 & 193 & 288 & 242 & 285 & $y=4.7 x+95.1$ & $0.80^{*}$ \\
\hline $\mathrm{Mg}\left(\mathrm{mmol}_{\mathrm{c}} \mathrm{kg}^{-1}\right)$ & 27.6 & 48.6 & 57.6 & 61.6 & 66.8 & $y=0.8 x+28.9$ & $0.84^{*}$ \\
\hline $\mathrm{H}+\mathrm{Al}\left(\mathrm{mmol}_{\mathrm{c}} \mathrm{kg}^{-1}\right)$ & 28.0 & 15.8 & 12.2 & 11.4 & 9.0 & $y=0.003 x^{2}-0.4 x+26.9$ & $0.95^{*}$ \\
\hline $\operatorname{CEC}\left(\mathrm{mmol}_{\mathrm{c}} \mathrm{kg}^{-1}\right)^{\mathrm{b}}$ & 148 & 259 & 360 & 317 & 363 & $y=5.1 x+153$ & $0.80^{*}$ \\
\hline $\mathrm{SB}(\%)^{\mathrm{c}}$ & 80.6 & 93.6 & 96.6 & 96.6 & 97.6 & $y=0.5 x+81.7$ & $0.89^{*}$ \\
\hline $\mathrm{S}\left(\mathrm{mg} \mathrm{kg}^{-1}\right)$ & 2.4 & 14.4 & 26.0 & 45.0 & 82.2 & $y=6.6 E-03 x^{2}+0.1 x+4.2$ & $0.83^{*}$ \\
\hline $\mathrm{B}\left(\mathrm{mg} \mathrm{kg}^{-1}\right)$ & 0.2 & 5.1 & 9.3 & 11.2 & 14.9 & $y=-5.5 E-04 x^{2}+0.20 x-0.36$ & $0.98^{*}$ \\
\hline $\mathrm{Cu}\left(\mathrm{mg} \mathrm{kg}^{-1}\right)$ & 5.3 & 15.8 & 25.0 & 22.9 & 29.8 & $y=0.4 x+5.9$ & $0.87^{*}$ \\
\hline $\mathrm{Fe}\left(\mathrm{mg} \mathrm{kg}^{-1}\right)$ & 55.0 & 56.8 & 58.8 & 56.2 & 47.4 & $y=0.2 x+54.3$ & $0.27^{*}$ \\
\hline $\operatorname{Mn}\left(\mathrm{mg} \mathrm{kg}^{-1}\right)$ & 52.3 & 34.0 & 26.8 & 19.9 & 15.6 & $y=0.003 x^{2}-0.7 x+51.4$ & $0.99^{*}$ \\
\hline $\mathrm{Zn}\left(\mathrm{mg} \mathrm{kg}^{-1}\right)$ & 1.9 & 134 & 220 & 226 & 325 & $y=4.6 x+12.9$ & $0.92^{*}$ \\
\hline $\mathrm{Cd}\left(\mathrm{mg} \mathrm{kg}^{-1}\right)$ & 0.02 & 0.2 & 0.4 & 0.4 & 0.8 & $y=1.4 E-05 x^{2}+5.5 E-03 x+4.9 E-02$ & $0.91^{*}$ \\
\hline $\mathrm{Cr}\left(\mathrm{mg} \mathrm{kg}^{-1}\right)$ & 0.01 & 0.01 & 0.02 & 0.02 & 0.03 & $y=1.6 E-07 x^{2}+7.9 E-06 x+0.01$ & $0.69^{*}$ \\
\hline $\mathrm{Ni}\left(\mathrm{mg} \mathrm{kg}^{-1}\right)$ & 0.6 & 1.2 & 1.6 & 1.7 & 2.5 & $y=2.2 E-05 x^{2}+1.5 E-02 x+0.7$ & $0.89^{*}$ \\
\hline $\mathrm{Pb}\left(\mathrm{mg} \mathrm{kg}^{-1}\right)$ & 1.5 & 12.3 & 35.3 & 24.1 & 18.3 & $y=0.9 x-0.4$ & $0.41^{*}$ \\
\hline
\end{tabular}

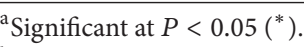

${ }^{\mathrm{b}}$ Cation exchange capacity $=\mathrm{Ca}^{2+}+\mathrm{Mg}^{2+}+\mathrm{K}^{+}+\mathrm{H}^{+}+\mathrm{Al}^{3+}$.

${ }^{c}$ Base saturation $=\left(\mathrm{Ca}^{2+}+\mathrm{Mg}^{2+}+\mathrm{K}^{+}+\mathrm{Na}^{+} / \mathrm{CEC}\right) * 100$.

soils [40]. The data presented in Table 3 are consistent with both statements, as the available contents of $\mathrm{Cd}$ were poorly affected by the soil $\mathrm{pH}$ and a low increase in Cu DTPA was observed above a rate of $50 \%$ contaminated soil.

Reduction in $\mathrm{Zn}$ mobility is usually associated with its adsorption to $\mathrm{Al}, \mathrm{Fe}$, and $\mathrm{Mn}$ oxides at $\mathrm{pH}$ levels higher than 5.5 [41]. A reduction in $\mathrm{Zn}$ availability was observed due to dilution of the contaminated soil, but when compared to the $\mathrm{pH}$ effect on $\mathrm{Cu}$ availability (Figure 1), $\mathrm{Zn}$ seemed to be more affected by the lime addition. This finding may be attributed to the higher $\mathrm{Zn}$ content in the soil mixtures because the total content of $\mathrm{Zn}$ was approximately 15 times higher than that of $\mathrm{Cu}$.

Boron is usually found in soils in its anionic form, which is highly available from pH 5.0 to 7.0 [42] and which corresponds to the range observed in the pot experiment. According to the literature, $B$ availability can be influenced by soil organic matter content and texture $[43,44]$. In the present study, because a small increase was observed in the organic matter content of the soil mixtures and a larger increase was observed for the B concentration in the same situation, there is no evidence of an organic matter effect on B availability (Table 3).

The concentration of both OM and B did not seem to be affected by liming (Table 3 ). A significant linear regression was obtained for OM and available B with increasing amounts of contaminated soil in the soil mixtures (Table 3 ). However, in both cases, one can conclude that this is exclusively due to the contribution of the contaminated soil content. A very small deviation was observed when a mass balance of such attributes was performed while considering the contaminated soil proportion in such mixtures.

According to van Raij et al. [34], concentrations of B above $0.6 \mathrm{mg} \mathrm{dm}^{-3}$ and of $\mathrm{S}$ above $10 \mathrm{mg} \mathrm{dm}^{-3}$ in soil are to be considered high for local soils. Values above such limits were observed for all of the proportion tested. In addition, the linear increase in $\mathrm{S}$ concentration in the soil mixtures with contaminated soil indicates that changes in $\mathrm{pH}$ did not affect the availability of S. A similar effect has been reported in the literature [45].

3.2. Dry Matter Yield and Element Contents in the Corn. Although symptoms of toxicity in plants were observed, this did not affect the dry matter yield. Visual evaluation of the plants 40 days after emergence evidenced purple and brown spotting, suggesting $\mathrm{P}$ deficiency in treatments without contaminated soil $(0 \%)$. The soil analysis showed lower concentrations of available $\mathrm{P}$ as the contaminated soil proportion increased in the soil mixtures (Table 3 ).

The $\mathrm{Zn}$ concentrations in the corn shoots varied from 46.1 to $454 \mathrm{mg} \mathrm{kg}^{-1}$, surpassing the level of $100 \mathrm{mg} \mathrm{kg}^{-1}$ considered to be adequate [35] for all proportion studied, except for the 0 proportion(uncontaminated soil). The toxic range for zinc in plants is reported as $100-400 \mathrm{mg} \mathrm{kg}^{-1}[25$, 46]. 
TABLE 4: Dry matter yield, element concentration, and adequate nutritional range for corn grown in the soil mixtures studied.

\begin{tabular}{|c|c|c|c|c|c|c|c|c|}
\hline \multirow{2}{*}{ Attributes } & \multicolumn{6}{|c|}{ Proportion of contaminated soil (\%) } & \multirow{2}{*}{ Equation } & \multirow{2}{*}{$\begin{array}{c}\text { Regression coefficient }{ }^{\mathrm{a}} \\
R^{2}\end{array}$} \\
\hline & 0 & 25 & 50 & 75 & 100 & Adequate range & & \\
\hline Dry matter $\left(\mathrm{g} \mathrm{pot}^{-1}\right)$ & 13.3 & 12.9 & 12.4 & 12.4 & 13.1 & & - & NS \\
\hline $\mathrm{N}\left(\mathrm{g} \mathrm{kg}^{-1}\right)$ & 29.1 & 27.7 & 26.9 & 27.2 & 26.5 & $27-35^{\mathrm{b}}$ & $y=2.9 E-04 x^{2}-5.2 E-02 x+28.9$ & $0.27^{*}$ \\
\hline $\mathrm{P}\left(\mathrm{g} \mathrm{kg}^{-1}\right)$ & 1.10 & 0.90 & 0.94 & 1.14 & 1.13 & $2.0-4.0^{\mathrm{b}}$ & $y=6.1 E-05 x^{2}-4.9 E-03 x+1.1$ & $0.28^{*}$ \\
\hline $\mathrm{K}\left(\mathrm{g} \mathrm{kg}^{-1}\right)$ & 39.3 & 47.9 & 48.1 & 49.7 & 49.9 & $17-35^{\mathrm{b}}$ & $y=0.3 x+40.2$ & $0.73^{*}$ \\
\hline $\mathrm{Ca}\left(\mathrm{g} \mathrm{kg}^{-1}\right)$ & 7.3 & 8.6 & 8.9 & 9.1 & 9.1 & $2.5-8.0^{\mathrm{b}}$ & $y=-3.1 E-04 x^{2}+4.8 E-02 x+7.4$ & $0.48^{*}$ \\
\hline $\mathrm{Mg}\left(\mathrm{g} \mathrm{kg}^{-1}\right)$ & 3.6 & 5.1 & 5.6 & 5.7 & 5.8 & $1.5-5.0^{\mathrm{b}}$ & $y=-3.61 E-04 x^{2}+5.5 E-02 x+3.7$ & $0.76^{*}$ \\
\hline $\mathrm{S}\left(\mathrm{g} \mathrm{kg}^{-1}\right)$ & 1.2 & 1.8 & 2.0 & 2.0 & 2.2 & $1.5-3.0^{\mathrm{b}}$ & $y=-1.1 E-04 x^{2}+2 E-02 x+1.3$ & $0.75^{*}$ \\
\hline $\mathrm{B}\left(\mathrm{mg} \mathrm{kg}^{-1}\right)$ & 25.7 & 315 & 572 & 779 & 950 & $10-25^{\mathrm{b}}$ & $y=12.5 x+24.8$ & $0.91^{*}$ \\
\hline $\mathrm{Cu}\left(\mathrm{mg} \mathrm{kg}^{-1}\right)$ & 7.5 & 8.9 & 11.6 & 9.8 & 13.0 & $6-20^{\mathrm{b}}$ & $y=-1.2 E-04 x^{2}+5.9 E-02 x+7.7$ & $0.51^{*}$ \\
\hline $\mathrm{Fe}\left(\mathrm{mg} \mathrm{kg}^{-1}\right)$ & 66.8 & 83.4 & 93.0 & 86.0 & 80.5 & $30-250^{\mathrm{b}}$ & - & NS \\
\hline $\operatorname{Mn}\left(\mathrm{mg} \mathrm{kg}^{-1}\right)$ & 112 & 43.8 & 46.0 & 55.2 & 67.5 & $20-200^{\mathrm{b}}$ & $y=0.02 x^{2}-2.23 x+104.4$ & $0.77^{*}$ \\
\hline $\mathrm{Zn}\left(\mathrm{mg} \mathrm{kg}^{-1}\right)$ & 46.1 & 276 & 328 & 359 & 454 & $15-100^{\mathrm{b}}$ & $y=6.92 x+71.5$ & $0.81^{*}$ \\
\hline $\mathrm{Cd}\left(\mathrm{mg} \mathrm{kg}^{-1}\right)$ & 0.22 & 0.34 & 0.32 & 0.26 & 0.42 & $0.1^{\mathrm{c}}$ & - & NS \\
\hline $\mathrm{Cr}\left(\mathrm{mg} \mathrm{kg}^{-1}\right)$ & 0.80 & 0.56 & 1.22 & 0.84 & 0.30 & $0.20^{c}$ & - & NS \\
\hline $\mathrm{Ni}\left(\mathrm{mg} \mathrm{kg}^{-1}\right)$ & 0.60 & 0.10 & 2.60 & 0.10 & 0.10 & $0.19^{c}$ & - & NS \\
\hline $\mathrm{Pb}\left(\mathrm{mg} \mathrm{kg}^{-1}\right)$ & 0.58 & 0.82 & 6.32 & 12.1 & 0.70 & $0.02^{\mathrm{c}}$ & $y=0.3 x-1.5$ & $0.30^{*}$ \\
\hline
\end{tabular}

${ }^{a}$ Significant at $P<0.05\left({ }^{*}\right)$ and not significant (NS).

${ }^{\mathrm{b}}$ van Raij et al. [34].

${ }^{c}$ U. C. Gupta and S. C. Gupta [35].

Other symptoms of toxicity and deficiency were observed in the shoots starting at the $25 \%$ proportion, such as chlorosis, necrosis, browning, spotting, and death of older leaves. The chlorosis of older leaves with evolution to necrosis has been associated with boron toxicity [42]. Similar symptoms of toxicity in corn due to excess B have also been reported, with toxic effects for most plants in the range of $50-200 \mathrm{mg} \mathrm{kg}^{-1}$ $[25,44,46]$. In the present work, the soil available B concentration increased with the addition of contaminated soil to the mixtures tested. This finding indicates that $\mathrm{B}$ availability was not affected by soil $\mathrm{pH}$. Plant analysis supported this statement, as B concentrations were found well above the nutritionally adequate range and accumulated in the corn shoots (Table 4, Figure 2).

Gabos et al. [47], in an experiment using the same contaminated soil employed in this study, tested organic matter amendments for the mitigation of contaminants and used sunflowers as the test plants; they also observed high levels of $\mathrm{B}, \mathrm{Cu}$, and $\mathrm{Zn}$ in the shoots regardless of treatment (385-374 $\mathrm{mg} \mathrm{kg}^{-1}$ for B; $305-289 \mathrm{mg} \mathrm{kg}^{-1}$ for $\mathrm{Cu}$, and $338-$ $473 \mathrm{mg} \mathrm{kg}^{-1}$ for $\mathrm{Zn}$ ). However, the plants showed no symptoms of B, Cu, or $\mathrm{Zn}$ toxicity. According to van Raij et al. [34], levels of 100,100, and $80 \mathrm{mg} \mathrm{kg}^{-1}$, respectively, for $\mathrm{B}, \mathrm{Cu}$, and $\mathrm{Zn}$ are considered adequate for sunflowers.

Toxicity in plants has been reported in the literature to occur for Cu from $20-100 \mathrm{mg} \mathrm{kg}^{-1}$, for $\mathrm{Mn}$ from $300-$ $500 \mathrm{mg} \mathrm{kg}^{-1}$, and for $\mathrm{Pb}$ from $30-300 \mathrm{mg} \mathrm{kg}^{-1}[25,46]$. No accumulation effect above the adequate range was observed for the $\mathrm{Cu}$ content in the corn shoots for all soil mixtures (Table 4), despite an increasing trend with an increase in available contents in the soil (Figure 2). Although a liming effect on Mn availability in the soil was clear, liming's nutritional impact on corn did not limit plant development or result in deficiency (Table 4). Lead accumulation in the corn shoots seemed closely related to the available contents of lead in the soil (Tables 3 and 4) but did not reach toxic levels.

Chromium, nickel, and cadmium concentrations in the corn shoots varied from 0.3 to $1.22,0.1$ to 2.6 , and 0.22 to $0.42 \mathrm{mg} \mathrm{kg}^{-1}$, respectively, surpassing the level of $0.2 \mathrm{mg} \mathrm{kg}^{-1}$ considered as adequate [35]. According to Macnicol and Beckett [48], levels above $8 \mathrm{mg} \mathrm{kg}^{-1}$ of $\mathrm{Ni}, 4 \mathrm{mg} \mathrm{kg}^{-1}$ of Cd, $2 \mathrm{mg} \mathrm{kg}^{-1}$ of $\mathrm{Cr}$, and $15-30 \mathrm{mg} \mathrm{kg}^{-1}$ of $\mathrm{Pb}[25,49]$ may cause toxicity in many plants, reducing their production. Although the available contents of $\mathrm{Cd}, \mathrm{Cr}$, and $\mathrm{Ni}$ were higher in the soil mixtures containing higher proportion of contaminated soil, such metals were not significantly found in the corn shoots (Table 4).

Nitrogen and iron absorption by the plants was not influenced by the rate of contaminated soil in the soil mixtures or by the soil $\mathrm{pH}$.

The correlation coefficients for the proportion of contaminated soil and the $\mathrm{Ca}, \mathrm{Mg}, \mathrm{S}$, and $\mathrm{K}$ concentrations in the shoots of the corn were significant (Table 4), with $\mathrm{Ca}, \mathrm{Mg}$, and $\mathrm{S}$ found to be within or close to the adequate nutritional range. The $\mathrm{Ca}$ and $\mathrm{Mg}$ concentrations in the shoots of the corn varied from 7.3 to 9.1 and 3.6 to $5.8 \mathrm{~g} \mathrm{~kg}^{-1}$, respectively, barely surpassing the levels of 8.0 and $5.0 \mathrm{~g} \mathrm{~kg}^{-1}$ considered as adequate [35] for all proportion studied except for the 0 rate (uncontaminated soil). The $\mathrm{S}$ and Fe concentrations in the shoots of the corn were considered as adequate for all proportion tested [35]. The $\mathrm{K}$ concentration in the shoots of the corn varied from 39.3 to $49.9 \mathrm{~g} \mathrm{~kg}^{-1}$, surpassing the level of 


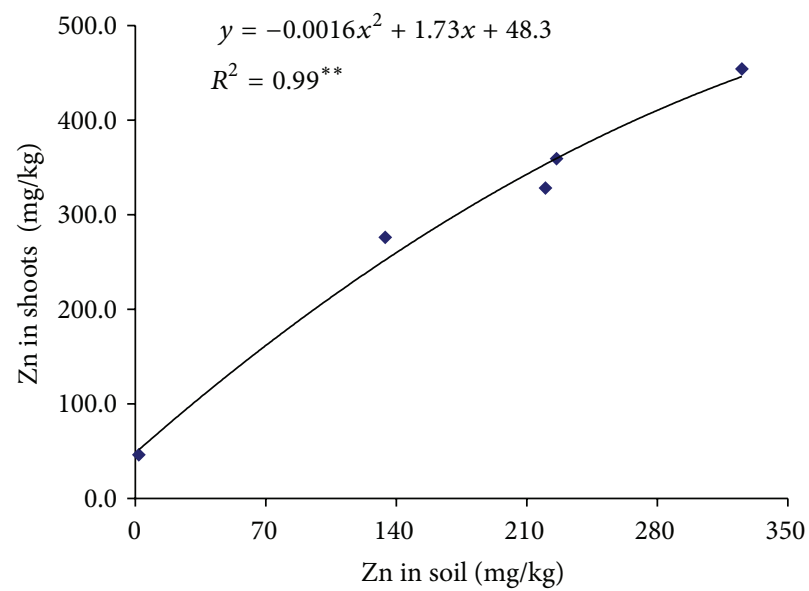

(a)

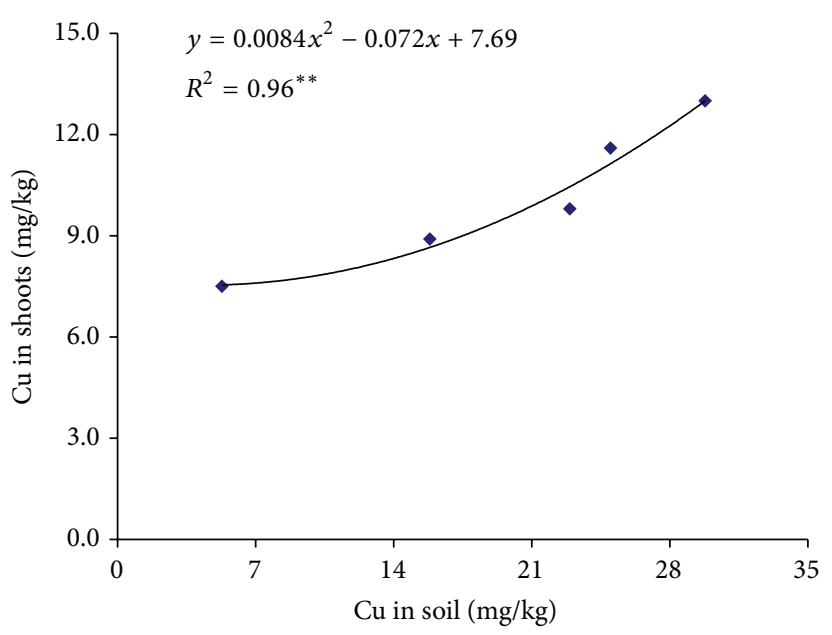

(c)

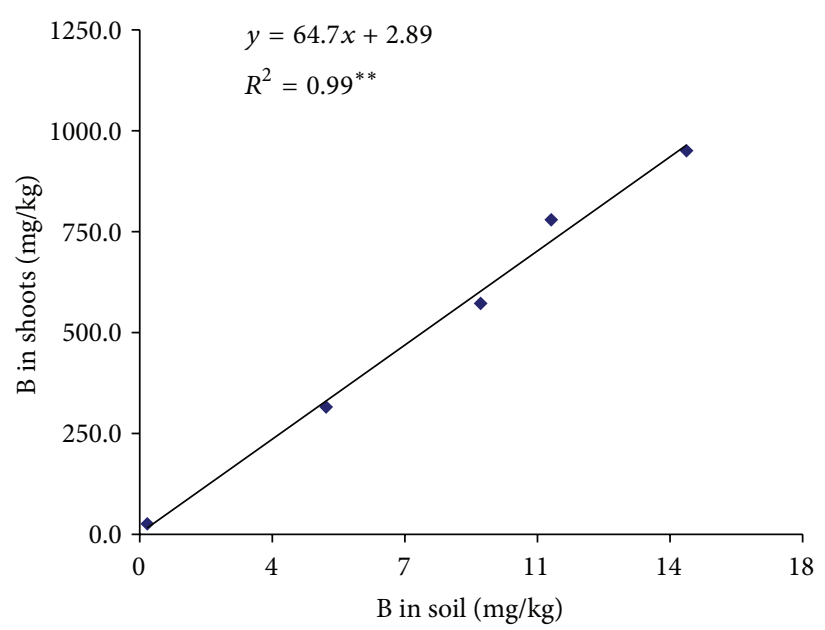

(b)

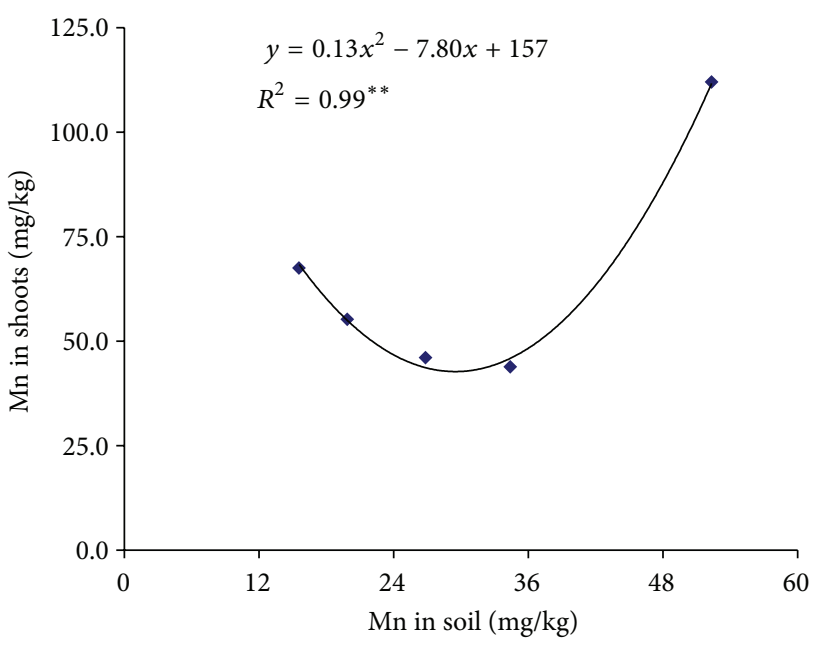

(d)

Figure 2: Corn shoots uptake and available content of elements in soil. ${ }^{* *}$ Significant at $P<0.01$.

$35 \mathrm{~g} \mathrm{~kg}^{-1}$ considered as adequate [35] for all proportion tested (Table 4).

\section{Conclusions}

The main contaminants present in the scrap metal residue were $\mathrm{Ba}, \mathrm{Cu}, \mathrm{Cr}, \mathrm{Ni}, \mathrm{Pb}, \mathrm{Zn}$, and $\mathrm{B}$, which increased total concentrations of these elements in the soil above the maximum content commonly found in the soils of São Paulo. Furthermore, the amounts of $\mathrm{Zn}, \mathrm{Cd}$, and $\mathrm{Pb}$ were above the intervention levels suggesting that a strategy should be made for soil remediation at this area.

Liming of $10 \mathrm{tha}^{-1}$ followed by soil dilution at any proportion studied was not successful for mitigation of the inorganic contaminants to a desired level of soil fertility, as demonstrated by the available amounts extracted by the DTPA method ( $\mathrm{Zn}, \mathrm{Pb}, \mathrm{Cu}, \mathrm{Ni}, \mathrm{Cr}, \mathrm{Cd}$ ) and hot water (B) still present in the soil. This fact was also proved by the phytotoxicity observed and caused by high amounts of $B$ and $\mathrm{Zn}$ accumulating in the plant tissue.

\section{Aknowledgment}

The authors are grateful to FAPESP project no. 2007/05635-3 for the financial aid.

\section{References}

[1] B. Mechri, F. B. Mariem, M. Baham, S. B. Elhadj, and M. Hammami, "Change in soil properties and the soil microbial community following land spreading of olive mill wastewater affects olive trees key physiological parameters and the abundance of arbuscular mycorrhizal fungi," Soil Biology and Biochemistry, vol. 40, no. 1, pp. 152-161, 2008.

[2] CETESB, “Texto explicativo: Relação de áreas contaminadas e reabilitadas no Estado de São Paulo," http://www.cetesb.sp.gov .br/userfiles/file/areas-contaminadas/2011/texto-explicativo .pdf, 2011.

[3] C. W. A. Nascimento and B. Xing, "Phytoextraction: a review on enhanced metal availability and plant accumulation," Scientia Agricola, vol. 63, no. 3, pp. 299-311, 2006. 
[4] U. Schmidt, "Enhancing phytoextraction: the effect of chemical soil manipulation on mobility, plant accumulation, and leaching of heavy metals," Journal of Environmental Quality, vol. 32, no. 6, pp. 1939-1954, 2003.

[5] B. Nowack, R. Schulin, and B. H. Robinson, "Critical assessment of chelant-enhanced metal phytoextraction," Environmental Science and Technology, vol. 40, no. 17, pp. 5225-5232, 2006.

[6] U. C. Gupta, Boron and Its Role in Crop Production, CRC Press, Boca Raton, Fla, USA, 1993.

[7] D. Akar, "Potential boron pollution in surface water, crop, and soil in the lower Buyuk Menderes Basin," Environmental Engineering Science, vol. 24, no. 9, pp. 1273-1279, 2007.

[8] U. Gemici and G. Tarcan, "Distribution of boron in thermal waters of western Anatolia, Turkey, and examples of their environmental impacts," Environmental Geology, vol. 43, no. 1-2, pp. 87-98, 2002.

[9] J. Ryan, M. Singh, and S. K. Yau, "Spatial variability of soluble boron in Syrian soils," Soil and Tillage Research, vol. 45, no. 3-4, pp. 407-417, 1998.

[10] M. Llugany, C. Poschenrieder, and J. Barceló, "Assessment of barium toxicity in bush beans," Archives of Environmental Contamination and Toxicology, vol. 39, no. 4, pp. 440-444, 2000.

[11] R. Suwa, K. Jayachandran, N. T. Nguyen, A. Boulenouar, K. Fujita, and H. Saneoka, "Barium toxicity effects in soybean plants," Archives of Environmental Contamination and Toxicology, vol. 55, no. 3, pp. 397-403, 2008.

[12] D. C. Adriano, W. W. Wenzel, J. Vangronsveld, and N. S. Bolan, "Role of assisted natural remediation in environmental cleanup," Geoderma, vol. 122, no. 2-4, pp. 121-142, 2004.

[13] P. Madejón, A. Pérez-de-Mora, P. Burgos, F. Cabrera, N. W. Lepp, and E. Madejón, "Do amended, polluted soils require retreatment for sustainable risk reduction? Evidence from field experiments," Geoderma, vol. 159, no. 1-2, pp. 174-181, 2010.

[14] J. H. Park, D. Lamb, P. Paneerselvam, G. Choppala, N. Bolan, and J. Chung, "Role of organic amendments on enhanced bioremediation of heavy metal(loid) contaminated soils," Journal of Hazardous Materials, vol. 185, no. 2-3, pp. 549-574, 2011.

[15] G. C. G. Santos and A. A. Rodella, "Efeitos da adição de fontes de matéria orgânica como amenizantes do efeito tóxico de $\mathrm{B}, \mathrm{Zn}$, $\mathrm{Cu}, \mathrm{Mn}$ e Pb no cultivo de Brassica juncea," Revista Brasileira de Ciência do Solo, vol. 31, pp. 793-804, 2007.

[16] J. C. Corrêa, L. T. Büll, W. S. Paganini, and I. A. Guerrini, "Disponibilidade de metais pesados em Latossolo com aplicação superficial de escória, lama cal, lodos de esgoto e calcário," Pesquisa Agropecuária Brasileira, vol. 43, pp. 411-419, 2008.

[17] É. E. C. De Melo, C. W. A. Do Nascimento, A. M. De Aguiar Accioly, and A. C. Queiroz Santos, "Phytoextraction and fractionation of heavy metals in soil after multiple applications of natural chelants," Scientia Agricola, vol. 65, no. 1, pp. 61-68, 2008.

[18] R. C. Nogueirol, L. R. F. Alleoni, F. J. C. Fracetto, D. Baretta, and C. E. P. Cerri, "Greenhouse gases emission from soil contaminated with automobile industry residue in Brazil," Plant and Soil, vol. 333, no. 1, pp. 315-323, 2010.

[19] US Environmental Protection Agency (USEPA), "Method 3051A: microwave assisted acid digestion of sediments, sludges, soil and oils," http://www.epa.gov/wastes/hazard/testmethods/ sw846/pdfs/3051a.pdf, 2007.

[20] B. van Raij, J. C. Andrade, H. Cantarella, and J. A. Quaggio, Análise Química para Avaliação da Fertilidade de Solos Tropicais, Instituto Agronômico, Campinas, Brazil, 2011.
[21] O. C. Bataglia, A. M. C. Furlani, J. P. F. Teixeira, and J. R. Gallo, Métodos de Análise Química de Plantas, Boletim Técnico 78, Instituto Agronômico, Campinas, Brazil, 1983.

[22] J. R. Sarruge and H. P. Haag, Análise Química em Plantas, Escola Superior de Agricultura Luiz de Queiroz, Departamento de Química, Piracicaba, Brazil, 1974.

[23] D. F. Ferreira, Programa SISVAR: Versão 4.6, Build 63, Lavras, Brazil, 1999.

[24] CETESB, "Decisão de diretoria n 195/2005-E de 23 de novembro de 2005," Dispõe sobre a aprovação dos Valores Orientadores para Solos e Águas Subterrâneas no Estado de São Paulo, vol. 115, no. 227, pp. 22-23, 2005.

[25] A. Kabata-Pendias and H. Pendias, Trace Elements in Soil and Plants, CRC Press, Boca Raton, Fla, USA, 3ed edition, 2001.

[26] W. L. Lindsay and W. A. Norvell, "Development of DTPA soil test for zinc, iron, manganese and copper," Soil Science Society of American Journal, vol. 42, pp. 421-428, 1978.

[27] E. Vidal-Vázquez, R. Caridad-Cancela, M. M. Taboada-Castro, A. Paz-González, and C. Aparecida De Abreu, "Trace elements extracted by DTPA and Mehlich-3 from agricultural soils with and without compost additions," Communications in Soil Science and Plant Analysis, vol. 36, no. 4-6, pp. 717-727, 2005.

[28] C. A. Abreu, B. van Raij, M. F. Abreu, and A. P. Gonzalez, "Routine testing to monitor heavy metals and boron," Scientia Agricola, vol. 62, pp. 564-571, 2005.

[29] B. J. Alloway, Heavy Metals in Soil, Blackie Academic \& Professional, London, UK, 1995.

[30] United States Department of Agriculture (USDA), "Heavy metals soil contamination," in Urban Technical Note, pp. 1-7, Soil Quality Institute, Auburn, Ala, USA, 3rd edition, 2000.

[31] R. M. Prado, M. C. M. Corrêa, A. C. O. Cintra, W. Natale, and M. A. C. Silva, "Liberação de micronutrientes de uma escória aplicada em um Argissolo Vermelho-amarelo cultivado com mudas de goiabeira (Psidium guajava L.)," Revista Brasileira de Fruticultura, vol. 24, no. 2, pp. 536-542, 2002.

[32] R. M. Prado and W. Natale, "Efeito da aplicação de escória de siderurgia ferrocromo na produção de mudas de maracujazeiro," Revista Brasileira de Fruticultura, vol. 26, no. 1, pp. 140144, 2004.

[33] C. L. Chenfang Lin, W. J. Busscher, and L. A. Douglas, "Multifactor kinetics of phosphate reactions with minerals in acidic soils: I. modeling and simulation," Soil Science Society of America Journal, vol. 47, no. 6, pp. 1097-1103, 1983.

[34] B. van Raij, H. Cantarela, J. A. Quaggio, and A. M. C. Furlani, Recomendações de Adubação e Calagem para o Estado de São Paulo, Boletim 100, Fundação IAC, Campinas, Brazil, 1997.

[35] U. C. Gupta and S. C. Gupta, "Trace element toxicity relationships to crop production and livestock and human health: implications for management," Communications in Soil Science and Plant Analysis, vol. 29, no. 11-14, pp. 1491-1522, 1998.

[36] L. D. King, "Retention of metals by several soils of the Southeastern United States," Journal of Environmental Quality, vol. 17, no. 2, pp. 239-246, 1988.

[37] S. Kuo and B. L. McNeau, "Effects of $\mathrm{pH}$ and phosphate on cadmium sorption by a hydrous ferric oxide," Soil Science Society of America Journal, vol. 48, no. 5, pp. 1040-1044, 1984.

[38] R. D. Harter, "Effect of soil pH on adsorption of lead, copper, zinc, and nickel," Soil Science Society of America Journal, vol. 47, no. 1, pp. 47-51, 1983.

[39] M. B. McBride, Environmental Chemistry of Soils, Oxford University Press, New York, NY, USA, 1994. 
[40] M. A. P. Pierangeli, L. R. G. Guilherme, N. Curi, M. L. N. Silva, J. M. Lima, and E. T. S. Costa, "Efeito do $\mathrm{pH}$ na adsorção e dessorção de cádmio em latossolos brasileiros," Revista Brasileira de Ciência de Solo, vol. 29, pp. 253-532, 2005.

[41] J. T. Moraghan and H. J. Mascagni Jr., "Environmental and soil factors affecting micronutrient deficiencies and toxicities," in Micronutrients in Agriculture, J. J. Mortvedt, P. M. Giordano, and W. L. Lindsay, Eds., pp. 371-425, Soil Science Society of America, Madison, Wis, USA, 2nd edition, 1991.

[42] U. C. Gupta, Y. W. Jame, C. A. Campbell, A. J. Leyshon, and W. Nicholaichuk, "Boron toxicity and deficiency: a review," Canadian Journal of Soil Science, vol. 65, no. 3, pp. 381-409, 1985.

[43] F. R. Silva and H. F. F. Ferreyra, "Boro total e solúvel e suas relações com alguns atributos dos solos do estado do Ceará," Revista Brasileira de Ciência do Solo, vol. 22, pp. 595-602, 1998.

[44] J. C. P. S. Lima, C. W. A. Nascimento, J. G. C. Lima, and M. A. Lira-Junior, "Níveis críticos e tóxicos de boro em solos de Pernambuco determinados em casa de vegetação," Revista Brasileira de Ciência do Solo, vol. 31, pp. 73-79, 2007.

[45] J. P. Dantas, "Boro," in Micronutrientes na Agricultura, M. E. Ferreira and M. C. P. da Cruz, Eds., Potafos/CNPQ, Piracicaba, Brazil, 1991.

[46] I. Pais and J. R. Jones, The Handbook of Trace Elements, St. Lucie Press, Boca Ratón, Fla, USA, 1997.

[47] M. B. Gabos, G. Casagrande, C. A. Abreu, and J. Paz-Ferreiro, "Uso da matéria orgânica como mitigadora de solo multicontaminado e do girassol como fitoextratora," Revista Brasileira de Engenharia Agrícola e Ambiental, vol. 15, no. 12, pp. 1298-1306, 2011.

[48] R. D. Macnicol and P. H. T. Beckett, "Critical tissue concentrations of potentially toxic elements," Plant and Soil, vol. 85, no. 1, pp. 107-129, 1985.

[49] M. Grün, H. Kronemann, W. Poedlesak, and B. Machelett, "Blei in der Umwelt: Pflanze," in Proceedings of the Mengenund Spurenelemente Arbeitst, pp. 201-215, Karl-Marx University, Leipzig, Germany, 1985. 

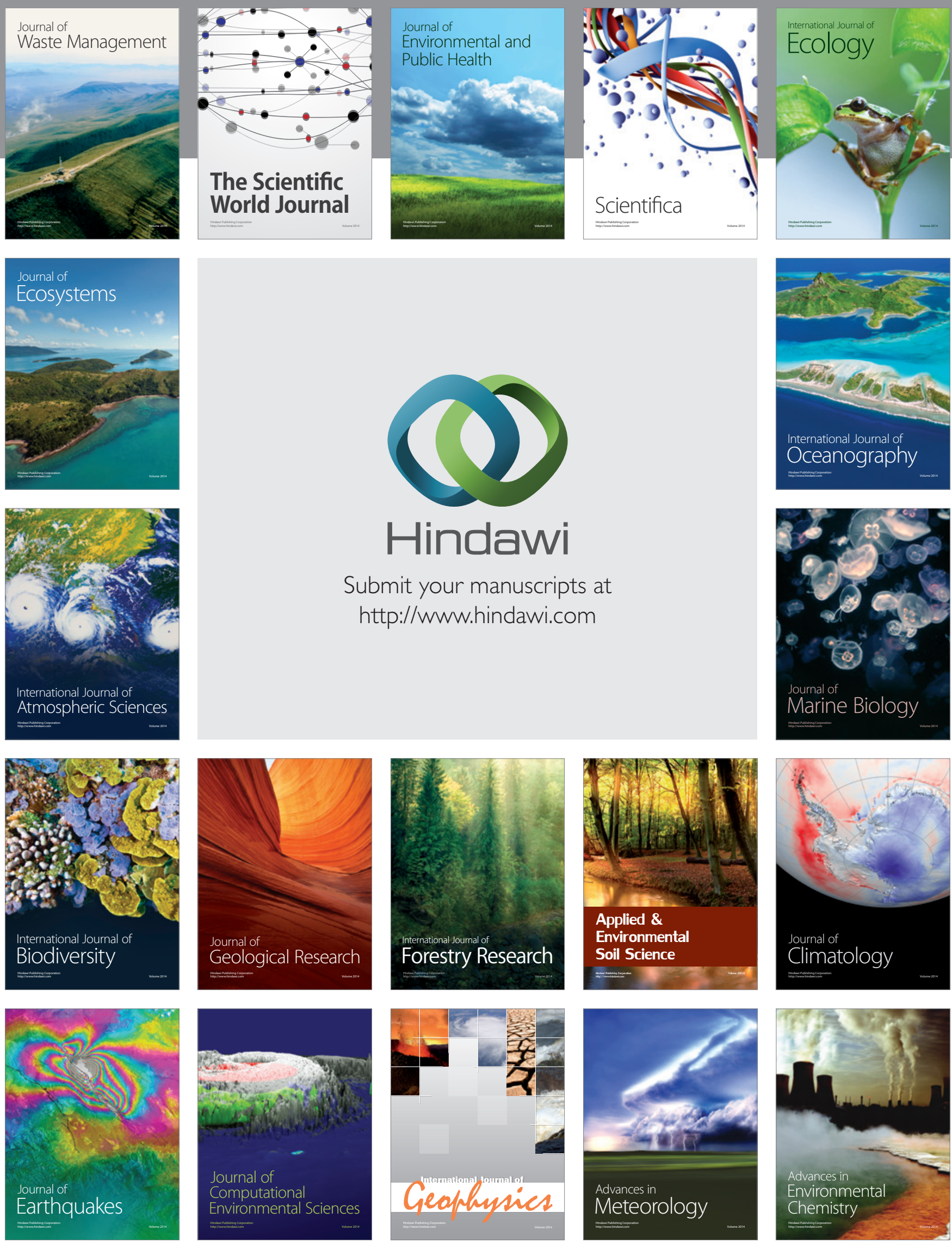